\title{
Przedmiot bistorii doktryn polityczno-prawnych w świetle analizy prakseologicznej. Propozycja narzędzia badawczego
}

\author{
Abstract \\ History of Political and Legal Thought in the Light of Praxeological Analysis. \\ Proposal on a Research Tool
}

The history of political and legal thought is a discipline of a clearly defined position. Its further development needs a continuous improvement in methodology and research tools. The use of methods designed by other scientific disciplines creates new perspectives here. The subject of the article is the attempt to use the elements of praxeological analysis to build a research tool useful for the interpretation of political and legal thought.

Keywords: history of political and legal thought, political thinking, praxeological analysis, law.

Słowa kluczowe: historia doktryn polityczno-prawnych, myślenie polityczne, analiza prakseologiczna, prawo.

\section{Wprowadzenie}

Badania prowadzone w ciągu kilku ostatnich dziesięcioleci pozwoliły względnie precyzyjne wyznaczyć pole zainteresowań historii doktryn polityczno-prawnych ${ }^{1}$. Jako podstawowy przedmiot dyscypliny należy wskazać, ewoluujący na przestrzeni dziejów,

1 Szerzej na temat współczesnego stanowiska naukowców o statusie dyscypliny zob.: Myślenie o polityce i prawie-przedmiot, metoda, praktyka, red. I. Barwicka-Tylek, A. Czarnecka, M. Jaskólski, J. Malczewski, Warszawa 2015; M. Jaskólski, Historia doktryn politycznych i prawnych ,jaka jest każdy widzi” [w:] idem, 13 różnych esejów o historii myśli politycznej i nie tylko, Warszawa 2013, s. 13 i nast.; Stownik historii doktryn politycznych, red. M. Jaskólski, t. 2, Warszawa 1999, s. 411-414. Spośród starszych opracowań zob. M. Jaskólski, Szkice o historii doktryn politycznych i prawnych, Warszawa-Kraków 1985; A. Czarnota, O historii doktryn polityczno-prawnych metodologicznie. Uwagi na marginesie książki Michała Jaskólskiego, „Czasopismo Prawno-Historyczne” 1988, t. XL (1), s. 159 i nast.; H. Olszewski, Stan i perspektywy badań 
namysł nad problematyką polityczno-prawną, niezależnie od jego cech, takich jak poziom ogólności, kompletność, spójność, zgodność z rzeczywistością itp. Perspektywa poznawcza, chociaż zbliżona do historii myśli politycznej, cechuje się jednak pewnym szczególnym rysem, wynikającym z odmiennego rozłożenia akcentów. O ile bowiem w przypadku badań nad myślą polityczną podstawowym przedmiotem zainteresowań może być w zasadzie każde zagadnienie mieszczące się w szeroko pojmowanej refleksji na temat zjawisk politycznych ${ }^{2}$, o tyle historia doktryn polityczno-prawnych powinna, z racji swoich prawniczych konotacji, przyjmować problematykę prawną, a czasem także prawniczą, jako jedno z centralnych zagadnień poznawczych. Założenie to rodzi pewne konsekwencje w praktyce. Z jednej strony zawężeniu ulega perspektywa badawcza, z drugiej natomiast prowadzona eksploracja uzyskuje stały punkt odniesienia, zapobiegający dryfowaniu ku ciągle nowym obszarom, do czego zachęca wieloznaczność myślenia politycznego ${ }^{3}$.

Względny konsensus wokół przedmiotu historii doktryn polityczno-prawnych nie oznacza jednak zakończenia prac nad rozwojem metod i technik badawczych. Przeciwnie, dyskusja nad doskonaleniem warsztatu naukowego historyków doktryn stanowi warunek sine qua non rozwoju dyscypliny. Obiecujące wydaje się, nawiązując do heurystycznej metody rozwiązywania problemów [TRoP] Edwarda $\mathrm{Nęcki}^{4}$, poszukiwanie inspiracji, metod poznania i opisu przedmiotowych zagadnień przy użyciu narzędzi oferowanych przez metodologię innych dyscyplin naukowych. Ich implementacja na gruncie wskazanego obszaru badawczego pozwali ukazać w nowym świetle problematykę uznawaną niejednokrotnie za wszechstronnie poznaną.

nad historia doktryn politycznych i prawnych. Wprowadzenie do dyskusji, „Czasopismo Prawno-Historyczne” 1996, t. XLVIII (1-2), s. 211 i nast.

2 The History of Political Philosophy, red. G. Klosko, Oxford 2011, s. 11-69; L. Strauss, J. Cropsey, Historia filozofii politycznej, przeł. P. Herbich i in., Warszawa 2010, s. 9-14; K. Grzybowski, Z zagadnień metodologii historii doktryn politycznych, „Czasopismo Prawno-Historyczne” 1956, t. VIII (1), s. $297-$ 310; J. Baszkiewicz, Historia ,,doktryn” $i$ historia ,,idei” politycznych (W zwiazku z książa pod redakcja J. Toucharda), „Państwo i Prawo” 1960 (3), s. 510-521; M. Sobolewski, Historia wspótczesnych doktryn politycznych, „Czasopismo Prawno-Historyczne” 1973, t. XXV (1), s. 131-155; idem, Niektóre problemy teorii i metodologii historii doktryn politycznych, „Historyka” 1976, t. VI, s. 3-17; J. Skrzypek, Z zagadnień nauki o doktrynach politycznych [w:] Metodologiczne i teoretyczne problemy nauk politycznych, red. K. Opałek, Warszawa 1975, s. 338-357; J. Maternicki, Ideologie historyczne jako przedmiot badań historycznych, „Studia Nauk Politycznych” 1986 (2/80), s. 19-41; E.M. Szymański, Ideologia. Struktura i zakorzenienie społeczne, „Studia Nauk Politycznych” 1987 (1/85), s. 137-156; K. Rudnicki, Doktryna polityczna jako przedmiot badań nauki o polityce, „Studia Nauk Politycznych” 1987 (2/86), s. 103-120; A. Zybertowicz, Kategorie do badania polskiej myśli politycznej (rozważania wstępne) [w:] Studia z dziejów polskiej myśli politycznej, T. 2: Polska myśl polityczna $w$ dzielnicy pruskiej w XIX w., red. S. Kalembka, Toruń 1990, s. 5-27; S. Filipowicz, Polska myśl polityczna XIX stulecia - uwagi o metodach i problemach badawczych [w:] Studia z dziejów polskiej myśli politycznej, T. 2: Polska myśl polityczna w dzielnicy pruskiej w XIX w., red. S. Kalembka, Torun 1990, s. 29-42; A. Czarnota, Zjawiska, stowa i stereotypy. Uwagi o kategoriach do badania polskiej myśli politycznej w dzielnicy pruskiej [w:] Studia z dziejów polskiej myśli politycznej, T. 2: Polska myśl polityczna w dzielnicy pruskiej w XIX w., red. S. Kalembka, Toruń 1990, s. 43-54.

3 W celu uniknięcia niejasności terminologicznych $\mathrm{w}$ dalszych rozważaniach historia doktryn polityczno-prawnych będzie rozumiana zgodnie z definicją Michała Jaskólskiego, który wskazywał, że jest to historia „mniemań i poglądów na strukturę polityczną społeczeństwa, w szczególności zaś państwo jako najważniejszy element tej struktury oraz na obowiązujące w społeczeństwie prawo". Stownik historii..., s. 413.

4 E. Nęcka, TRoP ... Twórcze Rozwiazywanie Problemów, Kraków 1994, s. 159 i nast. 
Nauką pozwalającą uzyskać nowe spojrzenie na przedmiot historii doktryn polityczno-prawnych jest prakseologia ${ }^{5}$. Z uwagi na uniwersalność dyrektyw oferowanych przez filozofię sprawnego działania aspirującą do roli metodologii ogólnej ${ }^{6}$, pojęcia oraz metody badawcze formułowane na jej gruncie, w szczególności makroprakseologii ${ }^{7}$, mogą okazać się użyteczne. Warto zatem postawić pytanie: Czy możliwe jest wykorzystanie dorobku prakseologii do opracowania narzędzia badawczego przydatnego dla historyków doktryn polityczno-prawnych? Zważywszy na fakt, że prowadzona na przestrzeni dziejów refleksja nad polityką, państwem i prawem wiązała się zazwyczaj z praxis, jak również na to, że jej charakter wpisuje się w prakseologiczną kategorię preparatoryki ${ }^{8}$, wstępna ocena przydatności wypada pozytywnie. Słuszność obranego kierunku poszukiwań potwierdzają również ustalenia dotyczące stosowania rozumowania sprawnościowego już przez sofistów i Arystotelesa9. Dlatego za uzasadnioną należy uznać próbę weryfikacji przydatności wykorzystania analizy prakseologicznej do badania myśli polityczno-prawnej.

\section{O specyfice historii doktryn polityczno-prawnych słów kilka}

Ze względu na to, że przedmiotem myśli polityczno-prawnej jest konkretny wycinek świata kultury stworzony przez człowieka, nawet najbardziej abstrakcyjne rozważania prowadzone w tym zakresie sprowadzają się do konkretnej sytuacji warunkowanej przez kontekst tworzony przez okoliczności miejsca i czasu. W obszarze myśli polityczno-prawnej szczególnego znaczenia nabiera, sygnalizowane wyżej, powiązanie refleksji intelektualnej z istniejącym porządkiem prawnym. Biorąc za punkt odniesienia instytucje prawne, historia doktryn polityczno-prawnych przyjmuje perspektywę epistemologiczną zbliżoną do strukturalizmu i poststrukturalizmu na płaszczyźnie antropologii kulturowej ${ }^{10}$. Dzięki takiemu rozłożeniu akcentów, pomimo odmiennego kontekstu powstania poszczególnych koncepcji polityczno-prawnych oraz ich odmienności w warstwie treściowej i językowej, prowadzone badania zyskują stały punkt odniesienia. Sprowadzenie poszczególnych koncepcji do wspólnego mianownika - prawa - ułatwia ich wpisanie w perennial debate about perennial problems ${ }^{11}$.

5 Szerzej zob. W. Gasparski, Uwagi o pojęciu sprawności, „Prakseologia” 1967 (27), s. 177 i nast.; idem, O pojęciu praktyczności, „Prakseologia” 1987-1988 (101), s. 57-68; Co dała i co dać może prakseologia innym dyscyplinom naukowym oraz praktyce? Stenogram z dyskusji zorganizowanej przez Redakcje 7 marca 1988 r., „Prakseologia” 1989 nr 3, s. 7 i nast.

6 J. Zieleniewski, Stan i osiagnięcia prakseologii oraz teorii organizacji w Polsce, „Prakseologia” 1971 (37), s. 18.

7 T. Pszczołowski, Mikro i makroprakseologia, „Prakseologia” 1980 (2), s. 115; L. Mises, Ludzkie dziatanie. Traktat o ekonomii [fragm.], „Prakseologia” 1996 (3-4), s. 57.

8 W dalszej części tekstu przedmiotowe zagadnienie zostanie wyjaśnione.

9 T. Pszczołowski, Zasady sprawnego działania, Warszawa 1967, s. 34 i nast., 52 i nast.

10 A. Barnard, Antropologia, zarys teorii i historii, przeł. S. Szymański, Warszawa 2016, s. 225 i nast., 255-264.

11 Szerzej na temat sporu wokół abstrahującej od miejsca i czasu debaty prowadzonej na poziomie filozofii politycznej zob. The History..., s. 16-17, 21-22. 
Na specyfikę badań prowadzonych w obszarze historii doktryn polityczno-prawnych w znacznym stopniu wpływa rodzaj dostępnego materiału źródłowego. Pomimo postępu technologicznego, który pozwolił wykorzystać jako nośniki ludzkich wypowiedzi zapis dźwięku oraz dźwięku i obrazu, językowa wypowiedź pisemna nadal zachowała fundamentalne znaczenie jako nośnik treści stanowiących przedmiot zainteresowania dyscypliny. Jeżeli zatem przyjmiemy, że myśl polityczno-prawna stanowi przejaw refleksji językowej nad określonym fragmentem rzeczywistości, historia doktryn polityczno-prawnych pełni rolę metajęzyka, którego przedmiot zainteresowań stanowi treść owej refleksji. Rodzi to pewne skutki w praktyce. Po pierwsze, jej przedmiot wpisuje się w prakseologiczną kategorię preparatoryki. Po drugie, za szczególnie przydatne należy uznać dwie metody badawcze właściwe naukom idiograficznym - analizę treści oraz analizę narracji ${ }^{12}$.

\section{Problematyka historii doktryn polityczno-prawnych z perspektywy prakseologicznej}

Wyznaczenie pola badawczego oraz określenie uwarunkowań metodologicznych pozwala na znalezienie powiązań między metodologią historii doktryn polityczno-prawnych i prakseologią. Poszukując obszarów wspólnych, należy zwrócić uwagę na cel myślenia politycznego. Obok aspektu eksplikacyjnego, uznawanego za jego cechę immanentną, poglądy wielu myślicieli zawierały również, a niekiedy przede wszystkim, elementy normatywne ${ }^{13}$. W prowadzonych rozważaniach dążyli oni do eksponowania rzeczywistych celów politycznych oraz środków do ich osiągnięcia. W tym sensie namysł nad działaniem politycznym należy uznać za element ich preparacji, rozumianej jako aktywność intelektualna antycypująca pożądane zdarzenia przyszłe ${ }^{14}$.

Opracowanie wizji nowej organizacji politycznej odzwierciedla zazwyczaj stosunek autora, wyrażony wprost lub implicite, do istniejącego modelu społeczeństwa, państwa oraz obowiązującego porządku prawnego. Prezentowane stanowisko zawiera także propozycję stanu idealnego, uzupełnioną niejednokrotnie o wskazanie koniecznych zmian do jego osiągnięcia (cecha doktryn kontestujących istniejący stan rzeczy) albo uzasadnienie utrzymania status quo jako optymalnego porządku instytucjonalnego (np. konserwatyzm). Skoro zakres pożądanych zmian bywa stopniowalny - począwszy od niewielkich modyfikacji aż do całkowitego przebudowania istniejącego porządku refleksję polityczno-prawną można uszeregować od stanowisk zachowawczych przez umiarkowane (ewolucyjne) aż do radyklanych (rewolucyjnych).

Właściwe przygotowanie każdego działania, a zatem również aktywności politycznej, stanowi przedmiot zainteresowań wspomnianej już preparatoryki. Badacze zajmu-

12 R. Bäcker i in., Metodologia badań politologicznych, Warszawa 2016, s. 161 i nast., 185 i nast.

13 W znaczeniu praktycznych wskazówek, jak osiągnąć pożądany stan rzeczy, a więc nie identyfikacja, jak jest, lecz określenie, jak być powinno. Zob. G. Ferrari, Stanowisko normatywne w prakseologii, „Prakseologia” 1989 (4), s. 49-63.

14 L. Mises, Ludzkie działanie..., s. 204 i nast. 
jący się poszukiwaniem metod sprawnego osiągania celów szybko dostrzegli istnienie zależności między namysłem i przygotowaniem działania a jakością jego wykonania w praktyce, bez względu na to, czy są to działania powtarzalne, czy pionierskie ${ }^{15}$. Ogół przygotowań odgrywa w omawianym modelu rolę poprzednika realizacji działań prowadzących od stanu obecnego do wyznaczonego celu, łącznie określanych jako następnik. Przygotowania natomiast dzielą się na związane z wykonywaniem czynności prostych (I stopnia) oraz na wymagające wykorzystania skomplikowanej wiedzy odnoszącej się do następników (II stopnia). W drugim z wymienionych przypadków są to szczególnego rodzaju koncepcyjne „działania nad działaniami”, czyli metadziałania, określane jako projektowanie lub planowanie. Cechą charakterystyczną metadziałań jest wykorzystywanie języka (znaków, kodu) opisującego działania, które mają lub powinny zostać zrealizowane ${ }^{16}$. Uwzględniając istotę i cel myślenia politycznego, refleksja tego rodzaju wpisuje się w model działania preparacyjnego II stopnia.

Dla właściwego zrozumienia istoty preparacji ważne jest uwzględnienie relacji dyrektyw sprawnościowych wobec epistemologicznego zagadnienia prawdy. O ile w przypadku wiedzy naukowej dążenie do prawdy jest celem samym w sobie, o tyle w wypad$\mathrm{ku}$ formułowania dyrektyw prakseologicznych stosowanie praw naukowych ma jedynie ograniczony zakres. Na płaszczyźnie historii doktryn polityczno-prawnych zwróciła na ten fakt uwagę Iwona Barwicka-Tylek, która - wykorzystując metaforę jengi - wyeksponowała różnicę między prawdą i sensem $\mathrm{w}$ myśleniu politycznym ${ }^{17}$.

W wypadku doskonalenia działań praktycznych dążenie do prawdy nie tylko bywa zbędne, ale niejednokrotnie może wpłynąć na obniżenie ich sprawności. Poszukiwanie prawdy bywa bowiem z punktu widzenia celów praktycznych nieekonomiczne ${ }^{18}$. Przyjmując właściwe dla myślenia sprawnościowego rozumowanie zgodne z kategoriami utylitarnymi, spośród konkurencyjnych koncepcji wyznaczających dostępne ścieżki postępowania wybrana powinna być ta, która pozwala osiągnąc zamierzony cel w sposób najprostszy oraz wymagający najmniejszych nakładów. Uznając za główne kryterium oceny pożądany efekt końcowy, za bliższe prawdy uznawane jest rozwiązanie, które znajduje pełniejsze odzwierciedlenie w praktyce. Można zatem skonstatować, że na płaszczyźnie prakseologicznej klasyczna koncepcja prawdy Arystotelesa przegrywa z pragmatyczną wizją prawdy ${ }^{19}$. Jest to konsekwencja odmienności celów, którym służą wspomniane propozycje. Tym, czym dla nauki są prawa naukowe (jako reguły poznawczo ugruntowane), tym dla nauk stosowanych są dyrektywy sprawnego działania -

15 T. Kotarbiński, Traktat o dobrej robocie, Wrocław 1982, s. 158 i nast.; W. Gasparski, Prakseologia, Warszawa 1999, s. 73; idem, Prolegomena do metodologii projektowania, „Prakseologia” 1972 (41), s. 5 i nast.; S.A. Gregory, Nauka o projektowaniu, „Prakseologia” 1972 (41), s. 21-35; W. Kieżun, Metodologia projektowania, „Prakseologia” 2001 (141), s. 9-15; A. Delorme, J. Woleński, Leon Petrażycki o znaczeniu przewidywań działalności praktycznej, „Prakseologia” 1984 (3-4), s. 103-110. Systematyczny wykład projektowania zob. Projektoznawstwo. Elementy wiedzy o projektowaniu, red. W. Gasparski, Warszawa 1988.

16 W. Gasparski, Prakseologia... s. 74; L. Mises, Ludzkie działanie..., s. 203.

17 I. Barwicka-Tylek, Prawda i sens. Dialektyka, marksizm, komunizm, Kraków 2016, s. 21-22, 22-31; L. Mises, Ludzkie działanie..., s. 95.

18 Nieekonomiczne w znaczeniu niekorzystnego stosunku poniesionych nakładów do osiągniętych efektów.

19 E. Anscombe, O prawdzie praktycznej, „Prakseologia” 1993 (3-4), s. 29-35; W. James, Pragmatyzm, przeł. W.M. Kozłowski, Warszawa 2009, s. 149 i nast.; T. Gadacz, Historia filozofii XX wieku. Nurty, T. 1: Filozofia życia, pragmatyzm, filozofia ducha, Kraków 2009, s. 335-336. 
reguły efektywne w praktyce, czyli przynoszące powodzenie w znaczącej liczbie praktycznych zastosowań. Ich cechą charakterystyczną jest przyjmowanie trzech, inaczej niż w logice klasycznej, wartości logicznych: nieskuteczne [0], nieokreślone [?], skuteczne $[1]^{20}$. Różnica między prawami naukowymi i dyrektywami sprawnego działania będzie zatem analogiczna do różnicy między wypowiedziami o charakterze opisowym i performatywnym.

Praktyczny przedmiot dociekań, jak również przyznanie prymatu koncepcji prawdy zbliżonej do tej, którą zaproponował James ${ }^{21}$, nasuwają potrzebę zbadania związku między założeniami epistemologicznymi metodologii zaproponowanej przez prakseologię i amerykańskiego pragmatyzmu. Namysł nad tym zagadnieniem wydaje się tym bardziej uzasadniony, gdy uwzględnimy, że jednym z głównych bodźców skutkujących rozwojem pragmatyzmu była próba ratowania kondycji moralnej społeczeństwa amerykańskiego doby industrializacji ${ }^{22}$. Tym samym amerykańskim filozofom przyświecał, podobnie jak Tadeuszowi Kotarbińskiemu ${ }^{23}$, cel etyczny - doskonalenie moralnego wymiaru ludzkiej kondycji. Należy zatem sformułować pytanie: Czy, a jeżeli tak, to w jakim zakresie, prakseologia pozostawała $\mathrm{w}$ bezpośrednich relacjach z pragmatyzmem amerykańskim?

Odpowiedzi na tak zadane pytanie należy szukać w rozważaniach twórcy polskiej szkoły prakseologicznej i jednocześnie prekursora systematycznych badań w tym obszarze, wspomnianego wyżej Tadeusza Kotarbińskiego. Badacz ten, w celu legitymizacji współtworzenia dyscypliny, skrupulatnie wskazywał potencjalnych antenatów własnych badań. W kręgu naukowców najbliższych pod względem odległości czasowej oraz przedmiotu zainteresowań wskazywał na badacza ukraińskiego Eugeniusza Słuckiego, Belga Georges'a Hosteleta i Rosjanina Aleksandra Bogdanowa ${ }^{24}$. Pośród myślicieli anglosaskich, których rozumowanie chociażby tylko w niewielkim stopniu uwzględniało problematykę prakseologiczną, wskazywał na George'a Herberta Meada (The Philosophy of the Act, Chicago 1938). Z pewnym jednak zażenowaniem wspominał, że wiedzę o tej pracy czerpał ze źródła pośredniego, artykułu zamieszczonego w „The Journal of Philosophy" (1946, Vol. 43/9). Ponadto, jak sam podkreślał, już po opublikowaniu pierwszego wydania Traktatu o dobrej robocie $(1955)^{25}$ natrafił na amerykańską pracę zbiorową, Toward a general theory of action (pierwsze wyd. 1951), której jednym $\mathrm{z}$ autorów był Talcott Parsons. Chociaż z wyraźnym zadowoleniem uznawał tok rozumowania autorów tego dzieła za zbieżny z własnymi założeniami filozofii sprawnego działania, nie wskazał jednak na inspiracje pochodzące $\mathrm{z}$ tego źródła ${ }^{26}$.

20 W. Gasparski, Prakseologia..., s. 79.

21 H. Buczyńska-Garewicz, James, Warszawa 1973, s. 85 i nast.

22 T. Gadacz, Historia ..., t. 1, s. 199 i nast.; H. Buczyńska-Garewicz, James ..., s. 25 i nast.; J. Chałasiński, Kultura amerykańska, Warszawa 1970, s. 95.

23 T. Kotarbiński, O istocie oceny etycznej [w:] idem, Wybór pism, T. 1: Myśli o działaniu, Warszawa 1957, s. 699-707; idem, Traktat o dobrej robocie, Wrocław 1982, s. 423; J. Woleński, Kotarbiński, Warszawa 1990, s. 109 i nast.

24 T. Kotarbiński, Traktat..., s. 16-18.

25 Jak również po opublikowaniu w 1913 r. pracy Szkice praktyczne, które Kotarbiński uważał za początek systematycznych prac nad założeniami filozofii sprawnego działania. Por. T. Kotarbiński, Traktat..., s. 423.

26 Ibidem, s. 19. 
Poszukując potencjalnych wspólnych źródeł prakseologii i pragmatyzmu, należy spojrzeć głębiej. Charles Sanders Peirce, John Dewey i William James wpisywali się w tradycję myśli Herberta Spencera oraz amerykańskiej szkoły socjologicznej ${ }^{27}$. Kotarbiński wprawdzie miał w swoim naukowym curriculum vitae pracę poświęconą utylitarystycznej etyce Milla i Spencera ${ }^{28}$, z czasem jednak poszedł w stronę radykalnego materializmu, który w jego wydaniu przybierał formę reizmu ${ }^{29}$. Uwzględniając przytoczone argumenty, uzasadnione wydaje się stanowisko zakładające brak bezpośrednich związków między prakseologią i pragmatyzmem. Podobieństwo założeń epistemologicznych omawianych nurtów należałoby zatem raczej wywodzić z podobnych źródeł inspiracji filozoficznej oraz okoliczności ich powstania. Warto zaznaczyć, że obydwa nurty pojawiły się w okresie drugiej rewolucji przemysłowej, powodującej gwałtowne przyspieszenie industrializacji, co skutkowało spiętrzeniem szeregu nowych problemów społecznych. Sytuacja ta mogła sprowokować powstanie niezależnie od siebie koncepcji będących odpowiedzią intelektualistów na rodzące się i nieznane dotychczas zagrożenia. Wart podkreślenia jest fakt, że w znacznej mierze w wyniku tych samych okoliczności zrodziły się także: zarządzanie, eugenika, cybernetyka i dwudziestowieczne dystopie ${ }^{30}$.

Uwzględniając uniwersalny charakter prakseologii oraz jej koncentrację na sprawnościowym aspekcie ludzkich działań, przytoczony punkt widzenia należy uznać za inspirującą próbę wzbogacenia katalogu narzędzi wykorzystywanych do badania myśli polityczno-prawnej. Warto w szczególności wskazać na próbę obiektywizacji proponowanych kryteriów analizy. Wojciech Gasparski zwrócił uwagę, że

[...] prakseologia [...] nie zajmuj[e] się tym, jakie powinno być znaczenie przypisane przez człowieka działaniu oraz jakimi jego działania być powinny lub być mogły, gdyby ludzie byli inspirowani przez filozofię wartości absolutnych. [...] Celem jest wszystko, do osiągnięcia czego ludzie zmierzają. Środkiem jest wszystko, co człowiek działający za takie uznaje ${ }^{31}$.

Wyeliminowanie pozasprawnościowych kategorii aksjologicznych rodzi sposobność prowadzenia analiz ograniczających niebezpieczeństwo nadmiernego wartościowania badanych koncepcji.

\section{Kategorie prakseologiczne a analiza myśli polityczno-prawnej}

Punktem wyjścia preparacji działań przyszłych jest, mniej lub bardziej uświadomiona, ocena istniejącej rzeczywistości. Wspomniane założenie dotyczy również myślenia politycznego i prawnego, chociaż z pewnym zastrzeżeniem. Badacze filozofii politycznej

27 J. Chałasiński, Kultura amerykańska..., s. 55, 85.

28 Por. T. Kotarbiński, Utylitaryzm w etyce Milla i Spencera [w:] idem, Wybór pism..., T. 1, s. 215 i nast.

29 T. Kotarbiński, Reizm somatyczny [w:] idem, Wybór pism, T. 2: Myśli o myśleniu, Warszawa 1958, s. 7 i nast.; J. Woleński, Kotarbiński, s. 33 i nast.

30 Poszukiwanie związków i źródeł inspiracji między nurtami intelektualnymi wymaga dogłębnych studiów porównawczych, przekraczających skromny cel artykułu, którym jest określenie przydatności siatki pojęciowej prakseologii do zbudowania narzędzia użyteczniego do badania myślenia politycznego.

31 W. Gasparski, Prakseologia ..., s. 57. 
słusznie zwrócili uwagę na fakt, że swobodne wyrażanie stanowiska, szczególnie krytycznego, na temat istniejących rozwiązań instytucjonalnych bywa utrudnione, a czasem niemożliwie. Co więcej, należałoby przyjąć, że swoboda wypowiedzi politycznej należała w przeszłości do rzadkości, a normą było jej ograniczanie ${ }^{32}$. Błędne jest zatem przyjmowanie za uniwersalne standardów charakteryzujących zachodnie demokracje liberalne, w szczególności swobodę wypowiedzi. Dlatego kluczowego znaczenia dla poprawnego odczytania niuansów myśli polityczno-prawnej - na co zwrócili uwagę przedstawiciele kontekstualizmu, John Greville Agard Pocock ${ }^{33}$ i Quentin Skinner ${ }^{34}$ oraz twórca semantyki historycznej Reinhart Koselleck ${ }^{35}$ - nabiera uchwycenie specyfiki kontekstu wypowiedzi danego autora. Okoliczności decydują bowiem niejednokrotnie o rzeczywistym sensie tekstów zawierających propozycje rozwiązań ustrojowych. Uwzględnienie tego elementu badań pozwala uniknąć stosowania uproszczonych analogii, wynikających z powierzchownych podobieństw, oraz daje szansę uchwycenia właściwego kontekstu, kluczowego dla rekonstrukcji rzeczywistego sensu analizowanych wypowiedzi.

Na przeciwległym biegunie w stosunku do stanu wyjściowego znajduje się cel, stanowiący pożądaną wizję przyszłej rzeczywistości. Jego osiągnięcie zostaje urzeczywistnione w wyniku realizacji zaplanowanych działań praktycznych ${ }^{36}$. Chociaż cel jest rzucony w przyszłość, projekcja owego stanu zostaje stworzona w świadomości twórcy w konkretnie określonym czasie rzeczywistym, stanowiąc planowany efekt końcowy konceptualizacji procesu przemian. Planowanego celu nie należy mylić z wynikiem uzyskanym po przeprowadzeniu faktycznych działań. W tym drugim przypadku mamy bowiem do czynienia z rzeczywiście osiągniętym skutkiem. Z tego względu jego ocena jest możliwa wyłącznie w ujęciu retrospektywnym, po zakończeniu działań ${ }^{37}$.

Dla właściwej interpretacji przejawów myślenia politycznego konieczne jest określenie istoty celu. W świetle perspektywy prakseologicznej stanowi on pochodną potrzeb, wywoływanych przez sytuacje przymusowe lub nęcące. Potrzeby utożsamiane są z doznawaniem braku czegoś niezbędnego lub pożądanego. Podkreślenia wymaga przy tym różnorodność potrzeb ludzkich, począwszy od biologicznych, warunkujących przetrwanie jednostki, do wyrafinowanych potrzeb wyższego rzędu ${ }^{38}$. Za sytuację przymusową uznaje się stan, w którym niepodjęcie koniecznego działania będzie skutkować nie tylko utrwaleniem niekorzystnego status quo, ale również istnieje zagrożenie pogorszenia sytuacji w porównaniu ze stanem, gdyby konieczna akcja została podjęta ${ }^{39}$. Jednocześnie, z uwagi na podkreślenie prawnego wymiaru prowadzonych badań, rozwiązania pro-

32 The History..., s. 25-26; K. Frieske, Politycy, eksperci i otoczenie, „Prakseologia” 1980 (2), s. 94-95.

33 Ibidem, s. 11-12; 16-17.

${ }^{34}$ Q. Skinner, The foundations of modern political thought, Vol. one: The Renaissance, Cambridge 2010, S. ix-XV.

35 R. Koselleck, Historia pojęć a historia społeczna [w:] idem, Semantyka historyczna, Poznań 2012, s. $128-152$.

36 M. Plisiecki, Cel w działaniu autotelicznym, „Prakseologia” 1992 (1-2), s. 167-173.

37 T. Pszczołowski, Prakseologiczna teoria ocen, „Prakseologia” 1967 (24), s. 40-42.

38 W. Gasparski, Prakseologia ..., s. 53; L. Mises, Ludzkie działanie ..., s. 111; T. Pszczołowski, Zasady ..., s. 125 .

${ }^{39}$ T. Kotarbiński, Szkice praktyczne [w:] idem, Wybór pism, T. 1, s. 16 i nast.; idem, Traktat..., s. 41-42; idem, Prakseologia ..., s. 53. 
ponowane w poszczególnych przypadkach myślenia politycznego można przełożyć na oczekiwania wobec porządku prawnego, a więc ując w postaci postulatów de lege lata i de lege ferenda. Warto dodać, że problematyka celu i wyniku ulega wzbogaceniu o pole rozważań poświęcone ich wzajemnej relacji, ściślej: zgodności lub rozbieżności.

Zdefiniowany na etapie preparacji działań efekt końcowy, w interesującym nas przypadku skutek aktywności politycznej, bywa osiągany w drodze przemian ewolucyjnych albo rewolucyjnych. Celem może być jednak także utrzymanie istniejącego porządku. Ostatni z wymienionych może na pierwszy rzut oka pozostawać w sprzeczności z wyobrażeniem sprawnego działania, utożsamianego $\mathrm{z}$ dążeniem do zmiany. W takiej sytuacji również jednak dochodzi do podjęcia akcji, tyle że wektor jej kierunku jest przeciwny do wektora zmian. Działalność zachowawców prowadzi do zrównoważenia potencjału zmian reprezentowanego przez przeciwników istniejącego porządku instytucjonalnego. Dlatego cel polityczny będzie w takim wypadku tożsamy $\mathrm{z}$ utrzymaniem istniejącego stanu rzeczy. Nietrudno wskazać przypadki wytężonego wysiłku intelektualnego ukierunkowanego na zbudowanie argumentacji uzasadniającej utrzymanie istniejącego $\mathrm{w}$ danym czasie i miejscu porządku instytucjonalnego, w tym porządku prawnego.

Zidentyfikowanie stanu wyjściowego oraz celu warunkuje określenie pozostałych parametrów analizy prakseologicznej. Ponieważ cel polityczny stanowi w koncepcji każdego twórcy myśli polityczno-prawnej zagadnienie kluczowe, przyjęcie perspektywy teleologicznej należy uznać za właściwe. W konsekwencji identyfikacja oraz ocena wszystkich elementów badanej koncepcji polityczno-prawnej zostaje zrelatywizowana do wyznaczonego celu. Pośród parametrów analizy należy wymienić: podmiot działania i/lub realizatora działania, kryteria oceny działań wynikające z preferowanego systemu wartości, zasoby oraz narzędzia niezbędne do transformacji stanu obecnego w stan pożądany, metody działania oraz otoczenie i okoliczności działania. Łącznie wspomniane elementy stanowią składowe działania w interesującym nas obszarze preparacji działań politycznych ${ }^{40}$.

W prakseologii działanie jest definiowane proces transformacji stanu istniejącego w pożądany. Występuje w roli pojęcia syntetycznego, obejmującego wszystkie pozostałe elementy prowadzące od stanu wyjściowego do celu. Jest to świadoma i ukierunkowana aktywność ludzka prowadząca do zmiany, odroczenia zmiany albo utrzymania status $q u o^{41}$. W omawianym rodzaju aktywności będzie to działanie zmierzające do osiągnięcia zdefiniowanego uprzednio celu politycznego, znajdującego odzwierciedlenie w porządku instytucjonalnym.

Analizę prakseologiczną pozostałych elementów działania należy zacząć od określenia podmiotu oraz realizatora ${ }^{42}$. Za podmiot przygotowywanych działań politycznych uznany będzie ten, kto definiuje cele oraz kogo wizja ma być realizowana. Podmiotem działania politycznego może być zatem sam twórca projektowanej wizji przyszłości, o ile dąży do realizacji koncepcji w praktyce, albo inna osoba lub decydent zbiorowy, o ile określa cele polityczne, które następnie mają zostać zrealizowane. W takiej sytuacji podmiot jest jednocześnie realizatorem działania. Nie wszystkie cele polityczne mogą

40 W. Gasparski, Prakseologia..., s. 44-45.

41 L. Mises, Ludzkie działanie..., s. 24-26, 62 i nast.; Z. Krasnodębski, Działanie i jego racjonalność w perspektywie prakseologicznej i socjologicznej, „Prakseologia” 1991 (1-2), s. 27 i nast.

42 W. Gasparski, Prakseologia... s. 48-49. 
jednak zostać zrealizowane bezpośrednio przez podmiot. Niejednokrotnie do realizacji potrzebne jest wykorzystanie współdziałania innych uczestników - realizatorów, którzy wypełniając przydzielone role, przyczyniają się do osiągnięcia celu pomimo braku wpływu na jego definiowanie.

Z punktu widzenia poprawności wniosków analizy badanej koncepcji polityczno-prawnej szczególną rolę odgrywają kryteria oceny przyjęte przez jej autora lub przypisywane przez niego podmiotowi lub realizatorom działania. Preferowany system wartości wpływa na określenie kategorii cenności, według której przeprowadzana jest ocena poszczególnych elementów bądź całego działania politycznego. Kryteria mogą być stosowane świadomie lub nieświadomie oraz mogą być wyrażone explicite bądź jedynie pośrednio. Ostateczny wybór celów oraz określenie innych elementów działania politycznego wiąże się zazwyczaj z oczekiwaną użytecznością przewidywanych skutków oraz subiektywną oceną prawdopodobieństwa osiągnięcia stanu pożądanego w przyszłości.

Dokonujący wyboru celu i sposobów jego osiągnięcia racjonalny podmiot działania powinien się kierować sprawnością metodologiczną rozumianą jako wykonanie wszystkiego, co w danych okolicznościach może zostać uczynione, aby zapewnić działaniu powodzenie ${ }^{43}$. Od niej należy odróżnić sprawność rzeczywistą działania, ocenianą z perspektywy rzeczywiście osiągniętego wyniku ${ }^{44}$. Przy tym cel pozostaje podstawowym punktem odniesienia wartościowania prakseologicznego. Porównanie alternatywnych sposobów osiągnięcia zamierzonego skutku pozwala wybrać najbardziej korzystny wariant spośród prowadzących do niego dróg lub ocenić zgodność zaplanowanego stanu rzeczy z uprzednio przyjętym wzorcem ${ }^{45}$. Drugi z omawianych przypadków nasuwa skojarzenie z koncepcją Weberowskiego typu idealnego ${ }^{46}$.

Jako kryteria wartościowania prakseologicznego przyjmuje się walory utylitarne działania. Podstawową rolę odgrywają efektywność oraz ekonomiczność. Obok nich istotne znaczenie ma korzystność. Skuteczność działania pozwala zweryfikować, czy lub w jakim zakresie osiągnięto cel. Ekonomiczność działania to parament określający stosunek osiągniętych wyników do poniesionych nakładów. Korzystność natomiast jest parametrem wskazującym, które z działań pozwala osiągnąć najlepszy skutek, określony jako różnica między wynikiem i nakładami ${ }^{47}$. Chociaż wspomniane walory mają w większym stopniu zastosowanie do działania niż do jego preparacji, zasługują na uwzględnienie. Pozwalają bowiem ocenić, w jakim stopniu autor danej koncepcji w ogóle uwzględnił prawdopodobieństwo realizacji swojej wizji w praktyce, oraz poniesienie jakich nakładów akceptował podczas dążenia do wyznaczonego celu politycznego.

43 Ibidem, s. 55.

44 J. Zieleniewski, Organizacja zespołów ludzkich. Wstęp do teorii organizacji i kierownictwa, Warszawa 1964, s. 225.

45 W. Gasparski, Wartościowanie działań, „Prakseologia” 1995 nr 1-2, s. 15 i nast.; L. Mises, Ludzkie dziatanie..., s. 28.

46 Por.: M. Weber, Gospodarka i społeczeństwo. Zarys socjologii rozumiejącej, przeł. D. Lachowska, Warszawa 2002, s. 15-16.

47 T. Pszczołowski, Prakseologiczna teoria ocen, „Prakseologia” 1967 (24), s. 22 i nast.; T. Kotarbiński, Traktat..., s. 104 i nast. 
Istotnym elementem analizy sprawnościowej jest identyfikacja wykorzystywanych narzędzi ${ }^{48}$. Jak zauważył Edward T. Hall, wszystkie narzędzia wykorzystywane przez człowieka stanowią ekstensje wzmacniające naturalne możliwości ludzkiego organizmu. Przy czym zalicza się do nich nie tylko proste narzędzia przedłużające lub wzmacniające kończyny lub zmysły, ale również nawet najbardziej skomplikowane rozwiązania oferowane przez współczesne nowoczesne technologie. Jest to spostrzeżenie istotne, ponieważ zdaniem Halla: „Człowiek uczy się używać własnych ekstensji, nie zwracając najmniejszej uwagi na to, co kryje się pod nimi, niektóre z nich mogą być bardzo skomplikowane, jak na przykład „narzędzia” nauki lub broń wojenna. [...] Całość kultury to skomplikowany system ekstensji”"49. W szerszym znaczeniu również instytucje polityczne i prawne należy uznać za szczególną kategorię ekstensji, pozwalających człowiekowi zachować względną kontrolę nad określonym wycinkiem rzeczywistości.

Z narzędziami ściśle wiąże się kolejna kategoria - zasoby. Na etapie preparacji szczególnego znaczenia nabiera rozróżnienie zasobów na informacyjne (w szczególności dotyczy to wiedzy) oraz energomaterialne. Mają one charakter relacyjny, ponieważ punktem oceny przydatności pozostaje cel, a szczególnego znaczenia nabiera utylitarny aspekt zasobów ${ }^{50}$.

Namysł nad zasobami oraz narzędziami otwiera szeroką perspektywę analityczną. Łącznie pozwalają bowiem na wyciągnięcie wniosków co do trafności doboru instrumentarium na drodze do uprzednio przyjętego celu politycznego. Ułatwia ten rodzaj oceny retrospektywny charakter badań historii doktryn polityczno-prawnych. Ujęcie takie pozwala także porównać założenia przyjęte przez autora badanej koncepcji ze skutkami praktyki polityczno-prawnej, której dotyczyły.

Skuteczność osiągania wyznaczonych celów w znacznej mierze jest uzależniona od zastosowanych metody działania, rozumianej jako sposób postępowania, którego zastosowanie w praktyce prowadzi do osiągnięcia zamierzonego rezultatu, czyli wyznaczonego uprzednio celu ${ }^{51}$. Metoda pozwala na poddanie procesu realizacji celu racjonalnej kontroli. Nawiązując do koncepcji Maria A. Bungego, za działanie racjonalne należy uznać takie, gdy podmiot wykorzystuje w najszerszym zakresie dostępną wiedzę, planuje jego przebieg, a także jest gotowy do wprowadzenia koniecznych modyfikacji, zarówno planu, jak i samego działania, w wyniku zmiany okoliczności. Na przeciwległym biegunie plasuje się działanie niezaplanowane, nierozważne, podejmowane pod wpływem impulsu, bez uprzedniego zgromadzenia niezbędnej wiedzy, a także z pominięciem ryzyka wystąpienia zjawisk niekorzystnych ${ }^{52}$. Pomiędzy tymi skrajnościami otwierają się szerokie możliwości zajmowania stanowisk pośrednich.

Dynamika rzeczywistości oraz nieustanna ludzka aktywność sprawia jednak, że pomimo najbardziej skrupulatnej preparacji działań zawsze pozostaje znaczny margines

48 J. Ostrowski, Narzędzia i kultura, „Prakseologia” 1986 (3-4), s. 9 i nast.

49 E.T. Hall, Poza kultura, przeł. E. Goździak, Warszawa 2001, s. 48.

50 W. Gasparski, Prakseologia... s. 57.

51 T. Pszczołowski, Mała encyklopedia prakseologii i teorii organizacji, Wrocław 1978, s. 117-118; W. Gasparski, Prakseologia... s. 64.

52 W. Gasparski, Prakseologia... s. 65-66. 
błędu, wynikający z niepewności sytuacji przyszłej oraz ograniczonej zdolności człowieka do identyfikacji wszystkich istotnych czynników determinujących daną sytuację ${ }^{53}$.

Nietrudno zauważyć, że wspomniana prawidłowość jest wyjątkowo trafna w stosunku do preparacji (tworzenia ideologii, doktryn, programów politycznych) oraz realizacji przedsięwzięć politycznych, w szczególności gdy uwzględnimy, że integralnym elementem działań tego rodzaju jest nieprzewidywalny czynnik ludzki.

Ważną rolę w analizie prakseologicznej odgrywa również kontekst, w którym działanie ma (lub miało) zostać podjęte. Łącznie wszystkie istotne uwarunkowania określane są mianem okoliczności działania. Prakseolodzy wyróżniają okoliczności wewnętrzne i zewnętrzne. Do pierwszych zalicza się walory intelektualne i fizyczne podmiotu/ realizatorów, które traktowane są jako suma umiejętności sprzyjających osiągnięciu wyznaczonego celu. Drugą kategorię okoliczności stanowią uwarunkowania wyznaczające zewnętrzną możność działania podmiotu/realizatora. Wspomniane okoliczności łącznie tworzą kontekst działania, wyznaczając także jego granice ${ }^{54}$.

Z perspektywy analizy prakseologicznej o kompletnej preparacji działania politycznego można mówić, gdy koncepcja zawiera wszystkie wymienione elementy składowe. Nie jest to jednak w przypadku myśli polityczno-prawnej sytuacja powszechna, ich twórcy bowiem rozkładają zazwyczaj akcenty zgodnie z własnymi preferencjami, często nie dbając o kompletność. Jako warunek sine qua non, pozwalający w ogóle mówić o preparacji działań politycznych, należy uznać wskazanie celu oraz kryteriów oceny projektowanych działań politycznych. Wspomniany zakres jest tożsamy z ,minimalnym opisem prakseologicznym". Jak podkreśla Gasparski:

Warunkiem wykonalności działania jest dysponowanie składowymi działania, przy czym składowe główne - cel i kryteria oraz metoda dane są ich opisem. Brak któregokolwiek ze składowych powoduje wystąpienie problemów praktycznych ${ }^{55}$.

$\mathrm{Z}$ punktu widzenia procesu badawczego braki lub przemilczenia w analizowanych poglądach polityczno-prawnych także stanowią cenną wskazówkę interpretacyjną.

\section{Propozycja narzędzia badawczego wraz z przykładowym jego zastosowaniem}

Za przydatną metodę analizy treści należy uznać arkusz kodowania (klucz kategoryzacyjny $)^{56}$ pozwalający zebrać, ustrukturalizować, a następnie zinterpretować, elementy wybranego przejawu myślenia politycznego. Klucz kategoryzacyjny stosowany w badaniach jakościowych, do których należy zaliczyć analizę prowadzoną w obszarze

53 L. Mises, Ludzkie działanie..., s. 125 i nast.; W. Gasparski, Prakseologia..., s. 67; idem, Partycypacyjny przyczynek do zagadnienia ekspertyz, „Zagadnienia Naukoznawstwa” 1988 (3-4), s. 639 i nast.

54 W. Gasparski, Prakseologia..., s. 60-62.

55 Ibidem, s. 47.

56 Por. W. Paruch, Konsekwencje definiowania myśli politycznej dla kwestionariusza badań politologicznych, „Humanities and Social Sciences” 2015, Vol. XX (22), s. 157 i nast. 
zainteresowań historii doktryn polityczno-prawnych, nie wymaga zachowania tak wysokiej precyzji, jak występuje to w przypadku badań ilościowych ${ }^{57}$. Niemniej jednak odpowiedzi na pytania dotyczące analizowanej treści powinny być na tyle wyczerpujące, by umożliwiły identyfikację najważniejszych cech badanej koncepcji, analizowanej z perspektywy sprawności planowanego działania politycznego.

Podczas formułowania klucza kategoryzacyjnego z pomocą przychodzą wolne od wartościowania innego niż teleologiczne kategorie analizy prakseologicznej. Jej elementy składowe pozwalają uchwycić najważniejsze elementy badanej koncepcji. Na rysunku 1 został zamieszczony przykładowy kwestionariusz badawczy uwzględniający podstawowe kategorie prakseologiczne.

\begin{tabular}{|l|l|}
\hline \multicolumn{1}{|c|}{ AUTOR } & \multicolumn{1}{c|}{ TYTUŁ DZIEŁA } \\
\hline Kontekst powstania dzieła & $\begin{array}{l}\text { Kto? Co? Kiedy? Jak? Dlaczego? } \\
\text { W jakich okolicznościach? W jakim celu? }\end{array}$ \\
\hline Ocena stanu istniejącego & pytania szczegółowe \\
\hline $\begin{array}{l}\text { Cel polityczny } \\
\text { (w tym porządek prawny) }\end{array}$ & $\begin{array}{l}\text { pytania szczegółowe, np. dotyczące } \\
\text { celów pośrednich, ubocznych itp. }\end{array}$ \\
\hline Kryteria (wartości) & pytania szczegółowe \\
\hline Podmiot działań politycznych & pytania szczegółowe \\
\hline Realizator działań politycznych & pytania szczegółowe \\
\hline Narzędzia & pytania szczegółowe \\
\hline Zasoby & pytania szczegółowe \\
\hline Metody działań politycznych & pytania szczegółowe \\
\hline Okoliczności działań politycznych & pytania szczegółowe \\
\hline
\end{tabular}

Rys. 1. Przykładowy kwestionariusz zawierający elementy analizy prakseologicznej

Źródło: opracowanie własne.

W zależności od potrzeb oraz wskazanych celów badawczych klucz kategoryzacyjny może zostać uzupełniony przez wprowadzenie szczegółowych podkategorii ściśle określających gromadzenie danych dotyczących konkretnych aspektów badanego materiału źródłowego. Decyzja będzie uzależniona od celów zamierzenia badawczego. Niekiedy wystarczy bowiem odpowiedź na poszczególne pytania w formie opisowej lub poprzez wybór alternatywnych odpowiedzi tak-nie [0-1]. W innych przypadkach konieczne może się okazać pogłębienie eksploracji, na przykład przez zastosowanie klasyfikacji lub typologii stanowiska wraz ze wzrostem nasilenia występowania danej cechy w badanej koncepcji $[0 \rightarrow 1]$. Opisana procedura umożliwia weryfikację wyników badań uzyskanych tradycyjnymi metodami.

57 R. Bäcker i in., Metodologia badań..., s. 179-180. 
Jako przykład praktycznego zastosowania zaproponowanego narzędzia posłuży analiza porównawcza tez reprezentantów dwóch orientacji politycznych: radykalnej Maurycego Mochnackiego, i umiarkowanie postępowej - Stanisława Barzykowskiego, dotyczących Królestwa Polskiego doby konstytucyjnej oraz genezy powstania listopadowego. Ze względu na ograniczenie rozmiaru artykułu poniżej zostanie przedstawiony jedynie zarys zastosowania przedmiotowego narzędzia. Pominięte zostaną pytania szczegółowe, niezbędne do pogłębionej analizy, oraz wizja porządku prawnego.

Zaproponowany przykład należy uznać za interesujący z kilku powodów. Po pierwsze, obrazuje próbę uporządkowania poglądów obu autorów według tych samych kryteriów. Po drugie, sprowadzenie rozważań do wspólnego mianownika pozwala zidentyfikować, które spośród wspomnianych elementów analizy zadecydowały o tym, że relacje dotyczące tych samych wydarzeń spowodowały tak znaczącą rozbieżność interpretacji i oceny faktów. I po trzecie, oparcie analizy na sformalizowanych kategoriach prakseologicznych pozwala zachować odpowiedni dystans zarówno wobec gloryfikowanych w polskiej historiografii radykalnych postaw środowisk niepodległościowych, jak i w stosunku do bardziej umiarkowanych oraz zachowawczych reprezentantów obozu ugodowego wobec zaborców.

\section{1) Kontekst powstania dzieł Mochnackiego i Barzykowskiego}

Przesłankami prezentacji stanowisk politycznych były: upadek powstania listopadowego i jego skutki. Mochnacki i Barzykowski ${ }^{58}$, jako aktywni uczestnicy powstania, opuszczali ziemie polskie wraz z falą emigracji. Poszukując odpowiedzi na pytanie o przyczynę klęski insurekcji, poprzedzili główną część rozważań analizą piętnastolecia konstytucyjnego. W ten sposób powstały, determinowane stanowiskiem politycznym, emigracyjne syntezy przedpowstaniowych dziejów Królestwa Polskiego. Z dwóch dzieł jako pierwsze ujrzało światło dzienne Powstanie narodu polskiego w roku 1830 i 1831 Mochnackiego. Do jego napisania skłoniła tego działacza i publicystę potrzeba przedstawienia własnej interpretacji wydarzeń, co miało zdemaskować pojawiające się nieprawdziwe opinie. Pomimo deklaracji o obiektywnym ich relacjonowaniu autor przyjął perspektywę środowisk radykalnych ${ }^{59}$. Pierwsze wydanie, zawierające dwa z czterech pierwotnie planowanych tomów (nieukończenie dzieła spowodowała przedwczesna śmierć autora) ukazało się w 1834 roku $^{60}$. Dzieło Barzykowskiego, pierwotnie noszące tytuł Pamiętniki, ukazało się jako Historya powstawania listopadowego dopiero w 1883 roku $^{61}$. Tekst, według deklaracji autora, został ukończony w 1838 roku (wydawca podawał w wątpliwość tę datę) i miał charakter polemiczny, jego bowiem celem było spro-

58 Szerzej na temat poglądów Maurycego Mochnackiego i Stanisława Barzykowskiego na temat Królestwa Polskiego zob. R. Kania, Między politycznym umiarkowaniem a radykalizmem niepodległościowym. Królestwo Polskie (1815-1830) w polemice Maurycego Mochnackiego i Stanisława Barzykowskiego [w druku].

59 Była to przyczyna konfliktu Mochnackiego z mającym sfinansować wydanie dzieła Wincentym Chełmickim. Jak wspominał Władysław Zamoyski, Chełmickiego „oburza bezstronność i umiarkowanie, bez których żadna historia nie może i nie powinna być pisana”. Za: S. Kieniewicz, Przedmowa wydawcy [w:] M. Mochnacki, Powstanie narodu polskiego w roku 1830 i 1831, t. I, Warszawa 1984, s. 8, 11-12.

60 Ibidem, s. 12-13.

61 Ër[...] A., Do czytelnika [w:] S. Barzykowski, Historya powstania listopadowego, t. I, Poznań 1883, s. L. i nast.; LXXII-LXXIII. 
stowanie - zdaniem Barzykowskiego nieprawdziwych - informacji zawartych w relacji Mochnackiego. Zajęte stanowisko wynikało, w znacznej mierze, z bliskiego związku autora z przywódcą obozu konserwatywno-liberalnego, księciem Adamem Jerzym Czartoryskim ${ }^{62}$.

2) Ocena istniejącej sytuacji

a) Mochnacki postrzegał Królestwo Polskie jako stan niewoli usankcjonowanej postanowieniami kongresu wiedeńskiego. Eksponował sprzeczność interesów rosyjskich i polskich. Odbudowa niepodległej Polski skutkowałaby bowiem wypchnięciem Rosji poza Europę. Zarzucał Aleksandrowi I obłudę oraz próbę stopniowego wynarodowiania Polaków. Powstanie listopadowe uznawał za naturalną konsekwencję rozstrzygnięć pokongresowych z 1815 roku, w szczególności próby połączenia niewielkiej monarchii konstytucyjnej z agresywną monarchią absolutną. Istnienie Królestwa Polskiego to okres nadużyć rządzących, w tym negatywnie ocenianych polskich elit politycznych współpracujących z caratem ${ }^{63}$.

b) Barzykowski uznał utworzenie Królestwa Polskiego za efekt wspaniałomyślności Aleksandra I wobec Polaków. Stanowisko cara wywodził z trzech przesłanek: pozostałości liberalnych ideałów młodości, oceny praktycznej przydatności rozwiązań konstytucyjnych przed ich zastosowaniem w Rosji, chęci utrwalenia na arenie międzynarodowej wizerunku postępowego władcy. Wskazywał na instrumentalne traktowanie „,sprawy polskiej” przez cara, wpisujące się w agresywną politykę ekspansji i podboju caratu. Sprawę polską Barzykowski postrzegał jako kwestię przetargową w rywalizacji Zachodu i Rosji o wpływy w środkowo-wschodniej Europie. Krytycznie oceniał orientację profrancuską polskich elit ${ }^{64}$.

3) Cel polityczny

a) Podstawowym celem w koncepcji Mochnackiego było dążenie do niepodległości Polski ${ }^{65}$.

b) Niepodległość Polski lub szeroka jej autonomia w ramach cesarstwa rosyjskiego stanowiły cel nadrzędny w koncepcji Barzykowskiego ${ }^{66}$.

4) Preferowane wartości prakseologiczne (kryteria)

a) Za podstawową wartość eksponowaną przez Mochnackiego należy uznać skuteczność polegającą na akceptacji dążenia do celu bez względu na potencjalne koszty jego osiągnięcia ${ }^{67}$.

b) Barzykowski starał się uwzględniać potencjalne nakłady w zestawieniu z założonymi celami politycznymi. Przyznawał zatem prymat ekonomiczności i korzystności działań politycznych ${ }^{68}$.

62 Ibidem, s. LXII-LXIII; LXX-LXXI.

63 M. Mochnacki, Powstanie narodu polskiego..., s. 69, 83-85, 131, 148, 211.

64 S. Barzykowski, Historya powstania listopadowego..., passim.

65 M. Mochnacki, Powstanie narodu polskiego..., passim.

66 S. Barzykowski, Historya powstania listopadowego..., s. 68, 130-148, 178-179.

67 M. Mochnacki, Powstanie narodu polskiego..., passim.

68 S. Barzykowski Historya powstania listopadowego..., s. 77-78, 80. 
5) Podmiot działań politycznych oraz jego antagoniści

a) Mochnacki uznawał za główny podmiot działań politycznych tajne organizacje skupiające radykalne środowiska patriotyczne. Za przeciwników politycznych uznawał Rosję oraz elity polityczne Królestwa Polskiego ${ }^{69}$.

b) Jako podmiot działań politycznych Barzykowski uznawał polskie elity polityczne, w tym: szlachtę, inteligencję, wojsko, organizacje patriotyczne rozbite przez tajną policję wielkiego księcia Konstantego. En bloc pozytywnie oceniał ich działalność w okresie konstytucyjnym, w szczególności postawę członków Sądu Sejmowego oraz politykę gospodarczą ministra skarbu księcia Franciszka Ksawerego Druckiego-Lubeckiego. Zarzucał im jednak także bierność i nieświadomy współudział w radykalizacji postaw środowisk patriotycznych. Za przeciwnika w drodze do celu Polaków uznawał Rosję ${ }^{70}$.

6) Realizator działań

a) Według Mochnackiego był nim zjednoczony naród polski pod przywództwem tajnych organizacji patriotycznych ${ }^{71}$.

b) Barzykowski utożsamiał realizatora celu z elitami politycznymi Królestwa Polskiego, w szczególności Sejm, który dysponował legitymacją do występowania $\mathrm{w}$ interesie narodu polskiego ${ }^{72}$.

7) Narzędzia i zasoby

a) Analiza sytuacji Królestwa Polskiego prowadziła Mochnackiego do wniosku, że Polacy dysponowali środkami niezbędnymi do prowadzenia skutecznej walki narodowowyzwoleńczej przeciwko caratowi. Jednocześnie z perspektywy liberalizmu ekonomicznego krytykował interwencjonizm gospodarczy władz Królestwa Polskiego, szczególnie politykę ministra skarbu ks. Druckiego-Lubeckiego ${ }^{73}$.

b) Barzykowski twierdził, że Polacy nie dysponowali ówcześnie narzędziami dającymi nadzieję na powodzenie zbrojnej konfrontacji z Rosją. Wskazywał na potencjał sprawczy instytucji ustrojowych, w szczególności Sejmu, oraz uzasadnioną niechęć elit politycznych do narażania narodu na nierówną walkę z caratem ${ }^{74}$.

8) Metody działań politycznych

a) Mochnacki akceptował wykorzystanie wszelkich dostępnych sposobów. Przede wszystkim opowiadał się za dążeniem do niepodległości Polski na drodze walki zbrojnej z Rosją ${ }^{75}$.

b) Barzykowski preferował walkę o ochronę polskich interesów na drodze legalnej przy wykorzystaniu dostępnych środków instytucjonalnych oraz uprawnień podmiotowych gwarantowanych w Konstytucji z 1815 roku. Podkreślał zawarte

\footnotetext{
69 M. Mochnacki, Powstanie narodu polskiego..., s. 50, 287.

70 S. Barzykowski Historya powstania listopadowego..., s. 77-78, 80, 107-111, 130-138, $178-179$.

M. Mochnacki, Powstanie narodu polskiego..., s. 287.

S. Barzykowski, Historya powstania listopadowego..., s. 274-276.

M. Mochnacki, Powstanie narodu polskiego..., passim.

S. Barzykowski, Historya powstania listopadowego..., s. 130-148, 178-179.

75 M. Mochnacki, Powstanie narodu polskiego..., s. 287, 302-304.
} 
w niej bardzo korzystne rozwiązania ustrojowe, uwzględniające także interesy chłopstwa i mieszczaństwa. Aprobował stopniowe, ewolucyjne wzmacnianie pozycji Polaków w istniejących warunkach. Nie łączył pierwotnie sprawy polskiej z ideą powstania zbrojnego. Jak podkreślał, na tę drogę Polacy zostali zepchnięci siłą w wyniku zaostrzenia polityki rosyjskiej ${ }^{76}$.

9) Okoliczności działań politycznych

a) Mochnacki uważał moment wybuchu powstania za właściwy. Podkreślał nasilenie niepokojów społecznych i ruchów niepodległościowych w Europie oraz słabość Rosji zaangażowanej w wojnę z Turcją. Podkreślał obstrukcję elit politycznych Królestwa Polskiego sabotujących powstanie ${ }^{77}$.

b) Barzykowski uznawał za niekorzystne zaostrzenie kursu caratu wobec Polaków, wynikające ze wzrostu nastrojów antypolskich pośród elit eesarstwa rosyjskiego. Główną przyczynę wybuchu powstania widział jednak w nieustannym szarganiu honoru żołnierskiego przez ks. Konstantego. Podkreślał, że powstańców zawiodło wyczucie sytuacji. Uważał bowiem, że należało czekać na rozwój wypadków we Francji i racjonalnie oceniać sytuację polityczną w Europie. Chłodna kalkulacja umożliwiłaby rozpoczęcie działań zbrojnych w optymalnym momencie ${ }^{78}$.

Na podstawie bardzo pobieżnej analizy porównawczej przeprowadzonej z wykorzystaniem klucza kategoryzacyjnego uwzględniającego kategorie prakseologiczne, pojawia się kilka interesujących (wymagających jednak dodatkowego potwierdzenia) wniosków. Przede wszystkim, poza kontekstem powstania dzieł, jedynie cel wyznaczonych działań politycznych w obu przypadkach był zbieżny. W pozostałych obszarach autorzy różnili się całkowicie w ocenie Królestwa Polskiego doby konstytucyjnej. Potwierdza to odmienne definiowanie podmiotów i realizatorów działań oraz ich przeciwników politycznych. Ponadto proponowali inne metody walki politycznej, inne też zasoby i narzędzia. W różny sposób postrzegali okoliczności działań, a nawet stan wyjściowy własnych analiz. Uwzględniając powyższe fakty, na szczególną uwagę zasługuje poziom subiektywizmu w ocenie tematu podejmowanego przez autorów. Na tym polu przeważał zdecydowanie Mochnacki, którego interpretacja znacznie bardziej odbiega od rzeczywistości. Ten stan rzeczy nie dziwi, gdy uwzględnimy źródła inspiracji. O ile Barzykowskiemu bliżej było do koncepcji oświeceniowych wzmocnionych przez wątki niemieckiej szkoły historycznej, o tyle Mochnacki występował jako zdeklarowany zwolennik idealizmu i romantyzmu. Okoliczności te wpłynęły niewątpliwie na sposób interpretacji ówczesnej sytuacji politycznej.

Różnica między stanem faktycznym i jego interpretacją potwierdza pogląd, że wyniki myślenia politycznego należy raczej oceniać przez pryzmat skutecznego oddziaływania na adresatów, niż ich zgodności z opisywanymi zagadnieniami. W tym zakresie prymat należy zdecydowanie przyznać Mochnackiemu przed Barzykowskim. Jego bowiem narracja zaważyła na sposobie postrzegania przez kolejne pokolenia zarówno samego

76 S. Barzykowski, Historya powstania listopadowego..., s. 180-182 i nast.

77 M. Mochnacki, Powstanie narodu polskiego..., s. 302-304, 317.

78 S. Barzykowski, Historya powstania listopadowego..., s. 274-276. 
Królestwa Polskiego, jak i powstania listopadowego, decydując o kształcie świadomości narodowej Polaków.

Podsumowując powyższe rozważania, należy podkreślić, że zaprezentowane ustalenia stanowią jedynie przykład obrazujący praktyczne zastosowanie opisanego narzędzia i nie aspirują do roli wyczerpującej prezentacji przedstawionego zagadnienia merytorycznego. Ostateczna weryfikacja wniosków wymaga pogłębionych studiów wykraczających poza cel tego artykułu ${ }^{79}$.

\section{Wnioski}

Narzędzie badawcze służące do badania myśli polityczno-prawnej skonstruowane z wykorzystaniem elementów analizy prakseologicznej można uznać za przydatne. W pierwszej kolejności należy potwierdzić, że problematyka stanowiąca przedmiot zainteresowania dyscypliny może zostać opisana przy użyciu kategorii prakseologicznych. Każdy ze wspomnianych elementów otwiera szerokie pole eksploracji, w tym tworzenia typologii i klasyfikacji porządkujących myśl polityczno-prawną. Położenie nacisku na inne aspekty materiału badawczego pozwala spojrzeć na ową myśl polityczno-prawną w innym świetle.

Dzięki zastosowaniu przedmiotowego narzędzia pojawia się możliwość sprowadzenia do wspólnego mianownika, a przez to także łatwiejszego porównania różnych stanowisk i poglądów, w ujęciu nie tylko synchronicznym, ale również diachronicznym. $\mathrm{Z}$ kolei prowadzenie analizy przy uwzględnieniu stałego punktu odniesienia - celu działań - chroni przed zniekształceniem wyników badań przez nadmierne eksponowanie indywidualnych preferencji badaczy. Dzięki wykorzystaniu siatki pojęciowej oferowanej przez filozofię sprawnego działania przedstawione narzędzie pozwala ocenić kompletność koncepcji danego autora oraz wskazać zagadnienia, które z racji pełnej preparacji działań powinny być uwzględnione, a jednak zostały przez niego pominięte. W tym kontekście warto również wspomnieć, że badana myśl polityczno-prawna, jako element przygotowujący praktyczne działania polityczne, może zostać skonfrontowana z przebiegiem rzeczywistych wydarzeń politycznych, do których się odnosiła. Dzięki temu rodzi się sposobność do potwierdzenia lub zakwestionowania słuszności diagnoz formułowanych przez poszczególnych autorów.

Odrębnym, a przy tym bardzo interesującym, zagadnieniem jest poszukiwanie wątków sprawnościowych formułowanych w myśli polityczno-prawnej w ciągu dziejów. Przyjęcie wspomnianej perspektywy eksploracji wiązałoby się z przejściem z poziomu zagadnień metodologicznych na grunt merytoryczny. Uwzględniając intuicyjną skłonność do formułowania przez człowieka dyrektyw sprawnego działania, uzasadniona wydaje się hipoteza, że zakres nasycenia przedmiotu historii doktryn polityczno-prawnych

79 Równie obiecującym zastosowaniem omawianego narzędzia może być analiza porównawcza dzieł tego samego autora, powstałych w różnym czasie i okolicznościach. Jako interesujący przykład można wskazać dzieła Stanisława Staszica z okresu Sejmu Wielkiego oraz doby Księstwa Warszawskiego i Królestwa Polskiego, a więc stanowiska powstałe w zupełnie innym kontekście. 
tego rodzaju rozumowaniem może być dużo większy, niż wynikałoby to z pierwszego skojarzenia, nakazującego łączyć przedmiotowe zagadnienie z doktryną realizmu politycznego ${ }^{80}$ lub pragmatyzmu amerykańskiego. Warto w tym miejscu dodać, że na gruncie polskiej myśli polityczno-prawnej istniały związki łączące prakseologię z marksizmem-leninizmem ${ }^{81}$.

Ze względu na nacisk położony na aspekty praktyczne szczególnie wartościowe może się okazać zastosowanie zaproponowanej metody do eksploracji rodzimej myśli polityczno-prawnej. Warto bowiem podkreślić, że polska historiografia, której założenia były formułowane w XIX wieku głównie pod wpływem niespełnionych aspiracji niepodległościowych wzmacnianych przez romantyzm, wykreowała etos zbrojnej walki o niepodległość, nadając przy tym specyficzny rys interpretacjom polskiej historii. Niesymetryczność rozłożenia akcentów powodowała, że największe uznanie znajdowały koncepcje głoszące konieczność dążenia do suwerenności niezależnie od ponoszonych kosztów. Skutkiem tego na rodzimym myśleniu politycznym zaciążyła gloryfikacja tradycji powstań narodowych oraz ich ideologicznej podbudowy, przy jednoczesnym deprecjonowaniu wszelkich projektów politycznych i działań organizatorskich zmierzających do wyzyskania w sposób optymalny dla polskiej racji stanu istniejącej sytuacji politycznej. Wspomniana asymetria poznawcza mogłaby zostać częściowo ograniczona dzięki analizie polskiej myśli polityczno-prawnej przy wykorzystaniu kategorii prakseologicznych, eksponujących utylitarne walory działań ludzkich.

Pośród słabych stron metody należy wskazać ograniczony zakres jej zastosowania ${ }^{82}$, a także dostępność alternatywnych metod i technik badawczych, które mogłyby zostać uznane za bardziej przydatne. Propozycja innej, nieznanej perspektywy poznawczej może spotkać się z jej zakwestionowaniem przez historyków doktryn polityczno-prawnych. Należy jednak podkreślić, że celem zaproponowanego narzędzia, zbudowanego z wykorzystaniem elementów analizy prakseologicznej, nie jest zastąpienie dotychczasowych metod badania myśli polityczno-prawnej, a jedynie ich uzupełnienie. Jako narzędzie pomocnicze pozwala na dokonanie triangulacji. Dzięki temu wyniki badań opracowanych na podstawie tradycyjnych metod mogą uzyskać dodatkowe uzasadnienie lub zostać sfalsyfikowane.

\section{Bibliografia}

Anscombe E., O prawdzie praktycznej, „Prakseologia” 1993 (3-4).

Barnard A., Antropologia, zarys teorii i historii, przeł. S. Szymański, Warszawa 2016.

Barwicka-Tylek I., Prawda i sens. Dialektyka, marksizm, komunizm, Kraków 2016.

Baszkiewicz J., Historia 'doktryn'i historia 'idei' politycznych (W związu z książka pod redakcja J. Toucharda), „Państwo i Prawo” 1960 (3).

Bäcker R. i in., Metodologia badań politologicznych, Warszawa 2016.

Chałasiński J., Kultura amerykańska, Warszawa 1970.

\footnotetext{
80 J. Kozielecki, Realizm i pseudorealizm, „Prakseologia” 1985 (3-4), s. 9 i nast.

81 Zob. Lenin a teoria i praktyka organizacji, „Prakseologia” 1970 (36).

82 L. Mises, Ludzkie działanie..., s. 87-89.
} 
Buczyńska-Garewicz H., James, Warszawa 1973.

Co dała i co dać może prakseologia innym dyscyplinom naukowym oraz praktyce? Stenogram $z$ dyskusji zorganizowanej przez Redakcje 7 marca 1988 r., „Prakseologia” 1989, nr 3.

Czarnota A., O historii doktryn polityczno-prawnych metodologicznie. Uwagi na marginesie książki Michała Jaskólskiego, „Czasopismo Prawno-Historyczne” 1988, t. XL (1).

Czarnota A., Zjawiska, stowa i stereotypy. Uwagi o kategoriach do badania polskiej myśli politycznej w dzielnicy pruskiej [w:] Studia z dziejów polskiej myśli politycznej, T. 2: Polska myśl polityczna $w$ dzielnicy pruskiej w XIX w., red. S. Kalembka, Toruń 1990.

Delorme A., Woleński J., Leon Petrażycki o znaczeniu przewidywań działalności praktycznej, „Prakseologia” 1984 (3-4).

Ër[...] A., Do czytelnika [w:] S. Barzykowski, Historya powstania listopadowego, T. I, Poznań 1883.

Ferrari G., Stanowisko normatywne w prakseologii, „Prakseologia” 1989 (4).

Filipowicz S., Polska myśl polityczna XIX stulecia - uwagi o metodach i problemach badawczych [w:] Studia z dziejów polskiej myśli politycznej, T. 2: Polska myśl polityczna $w$ dzielnicy pruskiej w XIX w., red. S. Kalembka, Torun 1990.

Frieske K., Politycy, eksperci i otoczenie, „Prakseologia” 1980 (2).

Gadacz T., Historia filozofii XX wieku. Nurty, T. 1: Filozofia życia, pragmatyzm, filozofia ducha, Kraków 2009.

Gasparski W., O pojęciu praktyczności, „Prakseologia” 1987-1988 (101).

Gasparski W., Partycypacyjny przyczynek do zagadnienia ekspertyz, „Zagadnienia Naukoznawstwa" 1988 (3-4).

Gasparski W., Prolegomena do metodologii projektowania, „Prakseologia” 1972 (41).

Gasparski W., Uwagi o pojęciu sprawności, „Prakseologia” 1967 (27).

Gasparski W., Wartościowanie działań, „Prakseologia” 1995, nr 1-2.

Gregory S.A., Nauka o projektowaniu, „Prakseologia” 1972 (41).

Grzybowski K., Z zagadnień metodologii historii doktryn politycznych, „Czasopismo Prawno-Historyczne" 1956, t. VIII (1).

Hall E.T., Poza kultura, przeł. E. Goździak, Warszawa 2001.

James W., Pragmatyzm, przeł. W.M. Kozłowski, Warszawa 2009.

Jaskólski M., Historia doktryn politycznych i prawnych ,,jaka jest każdy widzi” [w:] M. Jaskólski, 13 różnych esejów o historii myśli politycznej i nie tylko, Warszawa 2013.

Jaskólski M., Szkice o historii doktryn politycznych i prawnych, Warszawa-Kraków 1985.

Kania R., Między politycznym umiarkowaniem a radykalizmem niepodległościowym. Królestwo Polskie (1815-1830) w polemice Maurycego Mochnackiego i Stanisława Barzykowskiego [w druku].

Kieniewicz S., Przedmowa wydawcy [w:] M. Mochnacki, Powstanie narodu polskiego w roku 1830 i 1831, T. I, Warszawa 1984.

Kieżun W., Metodologia projektowania, „Prakseologia” 2001 (141).

Klosko G. (red.), The history of political philosophy, Oxford 2011.

Kotarbiński T., O istocie oceny etycznej [w:] T. Kotarbiński, Wybór pism, T. 1: Myśli o działaniu, Warszawa 1957.

Kotarbiński T., Reizm somatyczny [w:] T. Kotarbiński, Wybór pism, T. 2: Myśli o myśleniu, Warszawa 1958.

Kotarbiński T., Szkice praktyczne [w:] T. Kotarbiński, Wybór pism, T. 1: Myśli o działaniu, Warszawa 1957.

Kotarbiński T., Traktat o dobrej robocie, Ossolineum 1982.

Kotarbiński T., Utylitaryzm w etyce Milla i Spencera [w:] T. Kotarbiński, Wybór pism, T. 1: Myśli o działaniu, Warszawa 1957. 
Koselleck R., Historia pojęć a historia społeczna [w:] R. Koselleck, Semantyka historyczna, Poznań 2012.

Kozielecki J., Realizm i pseudorealizm, „Prakseologia” 1985 (3-4).

Krasnodębski Z., Działanie i jego racjonalność w perspektywie prakseologicznej i socjologicznej, „Prakseologia” 1991 (1-2).

Lenin a teoria i praktyka organizacji, „Prakseologia” 1970 (36).

Maternicki J., Ideologie historyczne jako przedmiot badań historycznych, „Studia Nauk Politycznych" $1986(2 / 80)$.

Mises L., Ludzkie działanie. Traktat o ekonomii [fragm.], „Prakseologia” 1996 (3-4).

Myślenie o polityce i prawie - przedmiot, metoda, praktyka, red. I. Barwicka-Tylek, A. Czarnecka, M. Jaskólski, J. Malczewski, Warszawa 2015.

Nęcka E., TRoP... Twórcze Rozwiązywanie Problemów, Kraków 1994.

Olszewski H., Stan i perspektywy badań nad historia doktryn politycznych i prawnych. Wprowadzenie do dyskusji, „Czasopismo Prawno-Historyczne” 1996, t. XLVIII (1-2).

Ostrowski J., Narzędzia i kultura, „Prakseologia” 1986 (3-4).

Paruch W., Konsekwencje definiowania myśli politycznej dla kwestionariusza badań politologicznych, „Humanities and Social Sciences” 2015, Vol. XX (22).

Plisiecki M., Cel $w$ działaniu autotelicznym, „Prakseologia” 1992 (1-2).

Projektoznawstwo. Elementy wiedzy o projektowaniu, red. W. Gasparski, Warszawa 1988.

Woleński J., Kotarbiński, Warszawa 1990.

Pszczołowski T., Mała encyklopedia prakseologii i teorii organizacji, Wrocław 1978.

Pszczołowski T., Mikro i makroprakseologia, „Prakseologia” 1980 (2).

Pszczołowski T., Prakseologiczna teoria ocen, „Prakseologia” 1967 (24).

Pszczołowski T., Zasady sprawnego działania, Warszawa 1967.

Rudnicki K., Doktryna polityczna jako przedmiot badań nauki o polityce, „Studia Nauk Politycznych" 1987 (2/86).

Skinner Q., The foundations of modern political thought, Vol. one: The Renaissance, Cambridge 2010.

Skrzypek J., Z zagadnień nauki o doktrynach politycznych [w:] Metodologiczne i teoretyczne problemy nauk politycznych, red. K. Opałek, Warszawa 1975.

Słownik historii doktryn politycznych, red. M. Jaskólski, t. 2, Warszawa 1999.

Sobolewski M., Historia współczesnych doktryn politycznych, „Czasopismo Prawno-Historyczne” 1973, t. XXV (1).

Sobolewski M., Niektóre problemy teorii i metodologii historii doktryn politycznych, „Historyka” 1976, t. VI.

Strauss L., Cropsey J., Historia filozofii politycznej, przeł. P. Herbich i in., Warszawa 2010.

Szymański E.M., Ideologia. Struktura i zakorzenienie społeczne, „Studia Nauk Politycznych” $1987(1 / 85)$.

Weber M., Gospodarka i społeczeństwo. Zarys socjologii rozumiejacej, przeł. D. Lachowska, Warszawa 2002.

Zieleniewski J., Stan i osiagnięcia prakseologii oraz teorii organizacji w Polsce, „Prakseologia” 1971 (37).

Zieleniewski J., Organizacja zespołów ludzkich. Wstęp do teorii organizacji i kierownictwa, Warszawa 1964.

Zybertowicz A., Kategorie do badania polskiej myśli politycznej (rozważania wstępne) [w:] Studia z dziejów polskiej myśli politycznej, T. 2: Polska myśl polityczna $w$ dzielnicy pruskiej w XIX w., red. S. Kalembka, Torun 1990. 